\title{
A Meta-analysis of Basic Human Values in Brazil: Observed differences within the country
}

\author{
Uma Meta-análise dos Valores Humanos Básicos no Brasil: Diferenças
} observadas no país ${ }^{1}$

» Cláudio V.TORRES² (Universidade de Brasília, Brasil)

» Juliana B. PORTO ${ }^{3}$ (Universidade de Brasília, Brasil)

» Luiza M. VARGAS ${ }^{4}$ (Universidade de Brasília, Brasil)

» Ronald FISCHER 5 (Universidade Victoria de Wellington, Nova Zelândia)

Abstract The objective of the present study was to conduct a meta-analysis to test differences in basic human values within Brazil, as measured by Schwartz' Values Scale (Schwartz, 1992). We conducted a literature review of relevant research published between 1994 through 2012. A total of 19 reports, including 52 samples, met the selection criteria. The studies included samples from all five Brazilian geopolitical regions $(\mathrm{N}=$ $14.0 \% ; \mathrm{NE}=28.0 \% ; \mathrm{CW}=24.0 \% ; \mathrm{SE}=24.0 \%$; and $\mathrm{S}=10.0 \%$ ), with a total of 8,994 respondents (college students: 11.5\%, professionals: 88.5\%). An ANOVA weighted by sample size was carried out for each of the 10 motivational types. Results suggested systematic value differences across the five regions of Brazil. Respondents from the Northeast and Southern regions showed a higher endorsement of Conservation values when compared to respondents from the Center-West region. Also, respondents from the Southern region showed a higher endorsement of the values of Stimulation and Universalism when compared to respondents from the Center-West region of Brazil. We use an eco-cultural approach to interpret these differences in terms of the socialization processes prevalent in each region, including their history of immigration and colonization.

Keywords:

values in brazil; basic human values; Schwartz Theory; values differences; meta-analysis.

Resumo O objetivo do presente estudo foi o de conduzir uma meta-análise para testar a variância dos valores humanos básicos no Brasil, medidos pelo Inventário de Valores de Schwartz (Schwartz, 1992). Uma revisão de literatura de pesquisas relevantes foi conduzida de 1994 à $2012 \mathrm{em}$ grandes sistemas de dados brasileiros. Um total de 19 estudos, incluindo 52 comparações, alcançaram o critério de seleção para entrada na análise. Os estudos incluíram amostras de todas as cinco regiões geopolíticas brasileiras ( $\mathrm{N}=14,0 \% ; \mathrm{NE}=28,0 \% ; \mathrm{CO}=24,0 \% ; \mathrm{SE}=24,0 \%$; e $\mathrm{S}=10,0 \%$ ), somando um total de 8.994 respondentes participantes nos estudos, tanto estudantes universitários (11,5\%), quanto profissionais (88,5\%). Uma ANOVA balanceada pelo tamanho da amostra foi conduzida para cada um dos 10 tipos motivacionais. Resultados sugerem a presença de diferenças sistemáticas na hierarquia dos valores humanos adotada pelos participantes das cinco regiões do Brasil. Respondentes das regiões Nordeste e Sul demonstraram um alto endosso de valores de Conservação, quando comparados aos respondentes da região Centro-Oeste. Além disso, respondentes da região Sul mostraram um maior endosso de valores de Estimulação e Universalismo, quando comparados aos respondentes da região Centro-Oeste do Brasil. Tais diferenças são interpretadas em termos do processo de socialização em tais regiões, incluindo sua história de imigração e colonização, seguindo uma abordagem eco-cultural. Palavras-chave:

valores no brasil; valores humanos básicos; Teoria de Schwartz; diferenças entre valores; meta-análise.

1 Sponsored by the Conselho Nacional de Desenvolvimento Científico e Tecnológico (CNPq), with a productivity grant to the author

2 Endereço para correspondência: SQS 108, Bloco K, Apt. 604; - CEP: 70347110 - Brasília - DF. Fone: (+55) 61 3242-0866, (+ 97) 5487-9123. Email: claudio.v.torres@gmail.com

3 Email: porto.juliana@gmail.com

4 Email: luiza.vargas@gmail.com

5 Email: Ronald.Fischer@vuw.ac.nz 
Resumen El objetivo del presente estudio fue conducir un meta-análisis para comprobar la variabilidad en los valores humanos básicos en el Brasil, medidos por el inventario de Valores de Schwartz (Schwartz, 1992). Fue realizada una revisión de la literatura de investigaciones relevantes publicadas entre 1994 y 2012 en las grandes bases de datos de Brasil. Un total de 19 estudios, incluyendo 52 comparaciones, alcanzaron el criterio de selección para hacer parte del análisis. Los estudios incluyeron muestras de todas las cinco regiones geopolíticas brasileñas ( $\mathrm{N}=14,0 \% ; \mathrm{NE}=28,0 \% ; \mathrm{CO}=24,0 \% ; \mathrm{SE}=24,0 \% ; \mathrm{e}=10,0 \%$ ), sumando un total de 8.994 participantes, entre estudiantes universitarios (11,5\%) y profesionales (88,5\%). Una ANOVA equilibrada por el tamaño de la muestra fue conducida para cada uno de los 10 tipos motivacionales. Los resultados sugieren que hay diferencias sistemáticas en la jerarquía de valores humanos básicos adoptada por los participantes de las cinco regiones de Brasil. Los encuestados de las regiones Nordeste y Sur demostraron un alto respaldo de valores de conservación, cuando comparados a los participantes de la región Centro Oeste. Además, los encuestados de la región Sur mostraron un mayor respaldo a los valores de Estimulación y Universalismo, cuando comparados a los participantes de la región Centro Oeste del Brasil. Tales diferencias son interpretadas en términos del proceso de socialización en tales regiones, incluyendo su historia de migración y colonización, siguiendo un enfoque eco-cultural. Palabras-clave:

Valores en el Brasil; valores humanos básicos; Teoría de Schwartz; diferencias entre valores; meta-análisis. 
A $\mathrm{n}$ area of continuing interest to academics and practitioners is how the human values endorsed by individuals influence their attitudes, decisions, and behaviors. Human values promote the interest of individuals or institutions by motivating or being a standard for evaluating actions. Feather (1982) suggests that the positive or negative experience with an object forms in the individual evaluative beliefs about this object (or part of it), that are believed to be the cause of the experience. The individual then summarizes all the evaluative beliefs about the object to form an attitude towards it. In a following step, the individual then aggregates his or her attitudes towards objects perceived to be similar. This abstraction process continues until it reaches the most abstract level of 'values'. Once human value preferences are formed, they are generalized to new objects that were not evaluated before. Human values influence attitudes, decisions and behaviors regarding new objects based on the assumption that the new object will reinforce the human values in the same way as the original object has. This hierarchical network is also known as the value-attitude-behavior system (Rokeach, 1968), and has been investigated by leading organizational theorists to explain the most diverse plethora of phenomena in organizations, from management (e.g., Smith et al., 1994), to organizational behavior (e.g. Triandis, 1994), passing by consumer behavior (e.g., Allen, 2000), informal influence in organizations (Smith et al., 2012), among others. Thus, the understanding of the differences in preference of human values within Brazil might be an useful tool for those researchers aiming to investigate how this variable can relate to several organizational events.

In Rokeach's (1973) seminal work, human values are defined as "an enduring belief that a specific mode of conduct or end-state of existence is personally or socially preferable to an opposite or converse mode of conduct or end-state of existence" (p. 5). Since Rokeach's (1973) proposition of a theory for the organization of beliefs, attitudes, and values, social psychologists have been focusing on the study of basic personal values, when comparing individuals from different social environments (Smith \& Bond, 1999). Examples of such comparisons can be found in the work of cross-cultural psychologists, who, with an empirical orientation, typically search for differences of specific behaviors in samples of several nations, or ethnic groups (Smith, Fischer, Vignoles, \& Bond, 2013). However, often we can find larger differences among the sub-cultures within a country than between cultures across countries. Cultures are systems of shared meanings. Although the countries deal with their internal diversity in order to establish the creation of national cultures, no country is monocultural (Smith \& Bond, 1999). For Smith, Fischer, Vignoles and Bond (2013), the best framework to guide research that involves culture is provided by studies of value differences, because the structure of individual values shows good consistency across cultures. Value differences are so substantial that they can help us interpret reported cultural differences. Porras and Robertson (1992) and Fischer and Schwartz (2011) observed that there is often bigger variance within a country in terms of values, than between countries. For instance, Latin America is composed of 22 countries, which have large cultural differences among them. Additionally, each country has sub-cultures or groups that differentiate among them. An example is the work of Hofstede, Hilal, Malvezzi, Tanure, and Vinken (2010) which demonstrated differences between Brazilian regions in the cultural-level of analysis. Because groups within a society can be differentiated in terms of a large number of criteria, the choice about which groups should be studied can be a difficult one. Poortinga and Sinha (1992) suggested that a criterion for distinction between groups should be made with regard to aspects of social behavior which do vary within that group. Yet, the majority of investigations that include human values as a variable consider the country as a homogeneous culture. In the present study, a meta-analysis was conducted with the objective of testing whether Brazilians would endorse the same values across the country, or whether there would be consistent value differences among the regions of Brazil. Thus, the study addresses the following research question: are there systematic differences in values endorsement across Brazil and its regions, as measured by Schwartz' Values Scale - SVS (Schwartz, 1992, 2005)? Is it justifiable to treat countries like Brazil as if they were homogeneous in terms of value?

It should be noticed, however, that the individual values measured by the SVS cannot be confused with cultural values. Although we developed what can be understood as an intra-cultural approach in the study (Georgas, Berry, Vijver, Kagitçibasi, \& Poortinga, 2006), our objective of investigating differences among the individual values endossed by residents of the five different regions of Brazil should not be mixed up with one that would address differences in the cultural values of these regions. An area of continuing interest to academics and practitioners is how the human values endorsed by individuals influence their attitudes, decisions, and behaviors. 
We can suppose that a lot of within-cultural variance may be found in Brazil. Quite different groups were formed in the country, what relates to the different parts of the world from which these groups originated. Yet, investigating such sub-cultures goes beyond the scope of this study. National culture, and its sub-culture variations, has been defined as patterns of thinking, feeling, and acting that are rooted in common societal conventions (Nakata \& Sivakumar 2001). What we want to observe here is how individuals, within a national culture, endorse their own personal values. As noticed by Smith et al. (2013, see also Fischer \& Poortinga, 2012), individual and cultural values are different constructs and variations in one level (e.g., individual) do not necessarily imply in differences at the other level (i.e., cultural). As in a number of studies, using mostly emic approaches, have looked at how individuals in a single national culture evaluate and build a hierarchy of values (e.g., de van Ruyter, Birgelen, \&Wetzels, 1998). Using an etic approach, the World Values Survey (Alexander, Inglehart, \& Welzel, 2011, see also Welzel, 2014) suggests that there are two major dimensions of values that vary among countries: traditional values (e.g., importance of religion, deference to authority etc.) versus secular values, and survival values (e.g., emphasis on economic, and physical security) versus self-expression values (e.g., emphasis on environmental protection, and tolerance). The general consensus is that individuals in different cultures utilize somewhat different values for evaluating social objects. For example, Mattila (1999) found that individuals of different cultures focus on different types of values to help them evaluate a social experience. She compared Western and Asian respondents, and found that individuals from Western cultures were more likely than their Asian counterparts to rely on hedonistic values when evaluating the consumption of a service.

The internal structure of basic values theory proposed by Schwartz has been shown to be adequate for Brazil (Campos \& Porto, 2010; Tamayo \& Schwartz, 1993). Tamayo and Schwartz (1993) demonstrated that structure fit well in Brazilian samples, but also that Brazilians scored low in intellectual and emotional autonomy, and high on conservatism and hierarchy. Other data confirm these findings. For instance, Pearson and Stephan (1998) found Brazil to be significantly high in tradition and conformity, and there is evidence that within Brazilian organizations, there appears to be little room for participation in problem solving (Torres, 2009), indicating a preference for conformity.

However, when we think of Brazil as the largest country in South America, occupying more than two-thirds of the Southern part of the American Continent, with a territory of more than $8,000,000 \mathrm{~km}^{2}$, and a population of approximately 200,000,000 inhabitants, can we seriously assume that it is justifiable to treat Brazil as if it was a homogeneous country in terms of its values endorsement? Logic would tell us that there shall be systematic differences in values endorsement across the country and its regions (Welzel, 2014). As pointed out by the World Values Survey based research (Li \& Bond, 2010), although leaning towards the adoption of traditional values, Brazil is in the border between survival and self-expression values, suggesting that different groups within the country endorse different values, and thus, making it acceptable that there are differences within regions of the country.

Within-culture differences can be due to assorted variables. As noted by Smith and Bond (1999), the population of a particular region within a country might subscribe to certain values in contrast to those endorsed in other regions (e.g., Smith et al., 1994; Triandis \& Gelfand, 1998). In the present case, as Ettorre (1998) observed, Brazil has radically changed its business climate from paternalistic and protected to one of free enterprise by the decade of 1990's. In this modern, changing economy of Brazil, there may be pressures for employees to present themselves as less conformity-oriented than they really are. Some research (Triandis, McCusker, \& Hui, 1990) has also shown a considerable cultural variation among regions of Brazil, with Southern Brazilians being more idiocentric (i.e., preferring individualistic values) than Northeastern Brazilians. Van Horn, Garian, Souza and Feijó (1995) provided further evidence that Brazil is not uniformly collectivist and also that there might be variation regarding power distance in different regions of the country. Studying middle- and upper-class mothers and college students in Southern Brazil, van Horn et al. (1995) observed college students from Southern Brazil tend to be low in power distance. Furthermore, the Brazilian college students were as idiocentric as American students when it came to self-reliance, interdependence, and distance from in-groups. They only expressed allocentric attitudes in terms of family integrity. Horn and Marques (1999) also found that middle class mothers from Southern Brazil were similar to their American counterparts in viewing their children as individuals with the right to exercise personal choice, and not recognizing a power differential in the parenthood-childhood relationship. 
Taken together, these studies provide some indication that individuals in Brazil might endorse different types of values, and that such variation might be associated with region of the country. Hofstede (1991, 1993) also found distinct culture profiles for the Brazilian's administrative regions in samples of workers. He found the South region to be more individualistic, hierarchical and masculine and less formal; the Southeast region was less masculine and shorter term-oriented; the Center-West was less formal; the Northeast was less hierarchical and masculine and more formal; and the North was more informal, masculine and collectivist. However, in Brazil, few studies have actually been conducted to investigate differences in the personal values of Brazilians, where the variable values was examined at the individual level. Most studies use supposed value-differences post-hoc to explain unpredicted results or pre-hoc to provide only context and background.

Considering the studies done in Brazil using the Schwartz Values Scale and the evidence of differences in the Brazilian culture, we conducted a meta-analysis to observe the variance of basic personal values within Brazil. This is the objective of the present study.

\section{HYPOTHESES DEVELOPMENT}

Brazil is indeed a very heterogeneous country in cultural terms. As noticed by Schwartz (Schwartz, 2011), "the future should see attention to cultural variations between groups within countries" (p. 316). Following this rationale, it is observed that different groups were formed in the country when individuals coming from the European immigration, Native Americans, and African slaves got together. The fact that Brazilians see themselves as members of an in-group, that they accept inequality and differences in status (i.e., social hierarchy), and that they have high income stratification (i.e., ratio of the high and low income), indicates that in Brazil as a whole, we would find a preference for conservation values, such as conformity, tradition, and security, over openness to change values. As discussed previously, a lot of variance can be attributed to withincultural differences. Due to its wide territorial extension and its colonization process in the $16^{\text {th }}$ Century, Brazil is relatively heterogeneous in cultural terms. For Ribeiro (1997), the country has a cultural division that originates from its social-economical history. Brazil has an extensive variety of weather and soil, which would be determinants of singular economic and social scenarios, leading to the division of the country into 5 Brazilian subcultures.

Ribeiro's division is not the only one recognized in Brazil. Regionalization, defined as the division of a certain space or territory into areas of common characteristics, can be created based on an array of several criteria. Physical characteristics, political, or economic aspects, and social-historical development are other criteria that have been used to develop regional divisions within Brazil. The choice among them depends on the objective that one wishes to accomplish, such as political interests, or specific economic aspects in consideration. Based on political motives, the first division of Brazil into regions was first proposed in 1938, and established in 1941 (Penha, 1993). Brazil was politically divided into 5 regions (Northern, Northeast, Central-West, East, and Southern). Later, in 1969, the East region was replaced by the Southeast region, and another modification of the original proposition was made in 1988, with the addition of another State into the Northern region. The 1969's division is still the Official geographical segmentation of Brazil. As originally proposed, it had the objective of centralizing the political power towards the Federal Government, and used as main criteria the region's climate, vegetation, and relief or landscape. Thus, it became known as the geopolitical division of the country. Using only the economic production as a criterion, Geiger (1967) proposed that Brazil should be divided only into 3 areas, which he named as geo-economic regions: the Amazon region, which, when compared to the previous geopolitical classification, would include all States of the Northern region, one State of the Central-West region, and another from the Northeast region. The Center-South region would be comprised by all remaining States of the Southern, Southeast, and Central-West regions, as well as one State of the Northern region. Finally, for the author, the Northeast region would coincide with the geopolitical division formely mentioned, with the exception of one State. The cultural and socio-economic division proposed by Ribeiro (1997) does not relate to Geiger's classification. Although Ribeiro's classification also does not entirely reflect the Official geopolitical division, it builds on it, in proposing 5 subcultures in Brazil. Here, we suggest that Ribeiro's historical and ethnically derived subcultures should relate to differences in values endorsement within the country. Thus, based on Ribeiro's (1997) classfication, if historical factors indeed lead to a preference for Conservation values, and if cultural differences among the regions of Brazil can actually be observed, then it is plausible to assume that: 
Hypothesis 1: Respondents from Brazil will differentially endorse values and that these differences are organized by region of residence in the country.

Ribeiro (1997) called the subculture in the Northeast region of the country the crioula culture. This region has a history characterized by the proliferation of sugarcane mills in the $17^{\text {th }}$ Century, constructed by the African slaves, under the orders of the Portuguese colonizers. In the crioula subculture, farmers and slave-owners established a very authoritative and quite patriarchal social system in these regions. The Northern region had a quite similar type of colonization, named by Ribeiro as the cabocla subculture, where Native Brazilians were used by the Portuguese colonizers as slaves. Non-voluntary immigrants like African slaves (Lesser, 2001), and Native Brazilians put a lot of emphasis on group norms, group loyalty, and the maintenance of their own survival, often in response to the exploitation suffered by the colonizers. The Southern region also had a strong influence of immigrants, but of European heritage. Especially Germans were highly influential in the formation of the Southern sub-culture, who between 1824 and 1832 arrived in this region, being recognizable in their traditions and costumes. Additionally, the exchanges between Native-Brazilians and Ibero-Europeans in the South formed an agriculture-based subculture, which strongly emphasizes their traditions and gender differentiation. So, we propose that individuals in the Southern, Northern, and Northeastern regions highly endorse Conservation values, such as Tradition, Conformity, and Security, as a result of the social tensions and colonization history in this part of Brazil. This strong emphasis in Conservation values may contrast with the Center-West region, due to its remarkable economical and political development after the transfer of the country's administrative Capital to Brasilia in 1960 (Torres \& Dessen, 2006). Although historically characterized as mainly an agricultural subsistence area prior to the move of the Capital to this inland, savanna-like part of the country, the transfer of the Capital to this region more than 50 years ago appears to have brought along an increase in the endorsement of Autonomy, Self-direction and other values that relate to Openness to Change. We propose increasing endorsement of personal-focused values (Schwartz et al., 2012) in the region due to its rapid economical development. Thus, we suggest that:

Hypothesis 2: Respondents from the Southern, North, and Northeast regions of Brazil will show higher endorsement of the values of Conservation, such as Conformity, Tradition, and Security, compared to respondents from the Center-West region. Participants from the latter region should report higher endorsement of values relating to Openness to Change, such as Self-direction, Stimulation, and Hedonism.

Ribeiro (1997) described the gaúcha subculture, formed by a distinct social group composed of descendants of European immigrants (mostly Italians and Germans) in the Southern region of Brazil. Due to its strong European influence, this region still keeps some of the cultural characteristics of its European immigrants (Oliven, 1992), leading to greater endorsement of values such as Universalism. Schwartz (1992) argued that Universalism is a motivational type that serves a mix of social and personal interests. Given the complexity of Universalism, we propose that the endorsement of Universalism should be high in the Southern region. The European immigrants in the South were driven to Brazil by their endorsement of a challenging life in the $17^{\text {th }}$ and $18^{\text {th }}$ Centuries, especially Germans, who between 1824 and 1832 arrived in this region, creating the "Mother Colonies" (Woortman, 2007) which were close to be little pieces of Germany in the country. Therefore, we should expect a higher endorsement of values in the Southern region that have a personal focus, such as Stimulation, as well as those that have a mixed focus between the personal and social interests, such as Universalism, when compared to the Center-West region. We propose:

Hypothesis 3: Respondents from the Southern region of Brazil will report a higher endorsement of the values of Stimulation and Universalism, when compared to respondents from the Center-West region of Brazil.

One issue still remains to be addressed when we discuss the Southeastern region of Brazil. The Brazilian Southeast region has been under a continuous industrialization process, which started in 1808 with the relocation of the Portuguese Court there. This region, and especially the state of São Paulo, was initially linked to gold and diamond mining, and later became a notable industrialized center of South America (Ettorre, 1998). Since the 1950 's, we have been observing a massive movement of multinationals to the Southeast due to its cheap labor and other favorable economic conditions, along with an internal migration of workers from especially the Northeast region, in search of a better pay when compared to their region of origin. Further, in the beginning of the $20^{\text {th }}$ Century, an agreement between the Brazilian and Japanese governments resulted in a large immigration of Japanese nationals to the country, who brought along their customs, strict social norms, and high respect for cultural traditions (Oliven, 1992). Most of those immigrants were settled in 
the Southern and Southeast regions of the country, where they remain to these days, supported mainly by agricultural practices and commerce (Gomes, 2008; Lesser, 2001). Today, Brazil hosts the largest group of Japanese immigrants in the world, estimated to be 1.5 million people (Instituto Brasileiro de Geografia e Estatítica [IBGE], 2012). The continuous industrialization process of the region suggests higher endorsement of values which reflect an individualist focus, whilst its colonization and immigration history suggests the adoption of values that are more directed towards Conservation, or group-centered values. Consulting the available research and literature, it is still not clear for us what would be the set of values mostly endorsed there. However, we could assume a tendency for increasing Conservation values in the region, due to its history as a region where Brazil was first colonized (Torres \& Dessen, 2008). Thus, we could expect the Southeast region to endorse traditional and conformity values. Value endorsements in the Southeast region deserve to be carefully investigated.

\section{METHOD}

\section{Literature search}

We conducted a literature review of relevant research from 1994 (the year the Schwartz Value Inventory SVS, was published in Brazilian Portuguese) through 2012 in the major Brazilian database - Scielo, and on dissertation database. The key words used in the search were: Values, Basic Human Values, Values in Brazil, Values Differences, and Schwartz Theory. We also sent messages to the major Brazilian researchers on human values looking for unpublished studies.

To be included in the meta-analysis, criteria were: a) studies should be empirical; b) should measure values using the Schwartz Values Inventory (1992); and, c) should specify the city or state of residence of the sample. Data regarding the residence of participants were later aggregated into the five geopolitical regions of the country (i.e., North $(\mathrm{N})=$ Acre, Amazonas, Pará and Tocatins; Northeast $(\mathrm{NE})=$ Alagoas, Bahia, Ceará, Maranhão, Paraíba, Pernambuco, Piauí, Rio Grande do Norte and Sergipe; Center-West (CW) = Distrito Federal, Goiás, Mato Grosso and Mato Grosso do Sul); Southeast (SE) = Espirito Santo, Minas Gerais, Rio de Janeiro and São Paulo; South (S) = Paraná, Santa Catarina and Rio Grande do Sul). A total of 19 reports, including 52 comparisons, met the selection criteria. These reports are presented in Table 1. The studies included samples from all five Brazilian Geopolitical regions $(\mathrm{N}=14.0 \% ; \mathrm{NE}=28.0 \% ; \mathrm{CW}=24.0 \%$; $\mathrm{SE}=$ $24.0 \%$; and $\mathrm{S}=10.0 \%)$. A total of 8,994 respondents participated in the studies, both college students (11.5\%), and professionals $(88.5 \%)$.

TABLE 1. Publications and reports used in the analyses

\begin{tabular}{|c|c|c|c|c|c|}
\hline Report & Author / Year & Source & $\begin{array}{l}\text { Number of } \\
\text { Samples }\end{array}$ & $\mathrm{N}$ & Region \\
\hline 1 & Tamayo (1994) & Psicologia: Teoria e Pesquisa, 9(2), 329-348. & 1 & 419 & Center-West \\
\hline 2 & Borges (2000) & $\begin{array}{l}\text { Technical Report. Federal University of Rio } \\
\text { Grande do Norte, Brazil. }\end{array}$ & 1 & 113 & Northeast \\
\hline 3 & Moreira (2000) & $\begin{array}{l}\text { Unpublished doctoral thesis. Institute of } \\
\text { Psychology, University of Brasilia, Brazil. }\end{array}$ & 2 & 548 & Center-West and North \\
\hline 4 & $\begin{array}{l}\text { Gouveia et. al } \\
\qquad(2001)\end{array}$ & Estudos em Psicologia, 6(2), 133-142. & 1 & 477 & Northeast \\
\hline 5 & Tamayo (2001) & $\begin{array}{l}\text { Revista de Administração Contemporânea, 5(3), } \\
\text { 127-147. }\end{array}$ & 1 & 192 & Center-West \\
\hline 6 & $\begin{array}{l}\text { Tamayo et. al } \\
\text { (2001) }\end{array}$ & Psicologia: Teoria e Pesquisa, 17(1), 27-35 & 1 & 200 & Center-West \\
\hline
\end{tabular}




\begin{tabular}{|c|c|c|c|c|}
\hline $\begin{array}{l}\text { Porto \& Tamayo } \\
\quad(2002)\end{array}$ & $\begin{array}{l}\text { Revista Psicologia: Organizações e Trabalho, } \\
\text { 2(1), 31-61 }\end{array}$ & 10 & 867 & $\begin{array}{l}\text { North, Northeast, } \\
\text { Center-West, South and } \\
\text { Southeast }\end{array}$ \\
\hline Tamayo (2002) & Revista de Administração da USP, 37(2), 26-37. & 1 & 177 & Center-West \\
\hline Gouveia (2003) & Estudos em Psicologia, 8(3), 431-443. & 1 & 252 & Northeast \\
\hline Lauer (2003) & $\begin{array}{l}\text { Unpublished master's dissertation. Center of } \\
\text { Philosophy and Humanities. Federal University of } \\
\text { Para, Brazil. }\end{array}$ & 1 & 431 & North \\
\hline Porto (2004) & $\begin{array}{l}\text { Unpublished doctoral thesis. Institute of } \\
\text { Psychology, University of Brasilia, Brazil. }\end{array}$ & 1 & 996 & Center-West \\
\hline Monteiro (2005) & $\begin{array}{l}\text { Unpublished master's dissertation. Center } \\
\text { of Social and Applied Sciences. Mackenzie } \\
\text { Presbyterian University, Brazil. }\end{array}$ & 1 & 40 & Southeast \\
\hline $\begin{array}{l}\text { Pantoja et. al } \\
\text { (2005) }\end{array}$ & Estudos de Psicologia de Natal, 10(2), 255-265. & 1 & 158 & Center-West \\
\hline Porto (2005) & $\begin{array}{l}\text { Unpublished master's dissertation. Institute of } \\
\text { Psychology, University of Brasilia, Brazil. }\end{array}$ & 1 & 209 & Center-West \\
\hline Fisher et al. (2007) & Journal of Cross-Cultural Psychology, 38(1), 3-18. & 1 & 153 & Southeast \\
\hline $\begin{array}{l}\text { Fernandes \& } \\
\text { Ferreira (2009) }\end{array}$ & Psico-Usf, 14(3), 341-354 & 1 & 311 & Southeast \\
\hline Alfinito (2010) & $\begin{array}{l}\text { Unpublished doctoral thesis. Institute of } \\
\text { Psychology, University of Brasilia, Brazil. }\end{array}$ & 24 & 2703 & $\begin{array}{l}\text { North, Northeast, } \\
\text { Center-West, South and } \\
\text { Southeast }\end{array}$ \\
\hline Felix (2010) & $\begin{array}{l}\text { Unpublished doctoral thesis. Institute of } \\
\text { Psychology, University of Brasilia, Brazil. }\end{array}$ & 1 & 362 & Southeast \\
\hline Fiuza (2010) & $\begin{array}{l}\text { Revista de Administração do Mackenzie, 11(5), } \\
\text { 55-81. }\end{array}$ & 2 & 386 & Center-West \\
\hline
\end{tabular}

In 1992, Schwartz examined the structure and relationships among items of the SVS via multidimensional scaling (MDS), which is a technique that presents the values as points in a multidimensional space, reflecting the "the empirical relations among values as measured by the correlations between their importance ratings. The greater the conceptual similarity between two values, the more related they should be empirically, and hence the closer their locations should be in the multidimensional space" (Schwartz, 1992; p. 21). Schwartz (1992) computed coefficients Alpha for each value type in his heterogeneous samples, obtaining reliability indexes that varied from .75 to .55. Later on, Schwartz et al. (2012) suggested that the Index of Quality (IoQ; Saris \& Gallhofer, 2007) as an applicable measure of reliability to the Values Scale. The IoQcorresponds to the correlation between the latent variable and the observed variables, and the squared IoQ can be interpreted as the percentage of variation explained by the observed composite score, which can be attributed to the true variable of interest. Perhaps due to this variety of techniques used to assess the reliability indexes to be used with the SVS, such indexes were not reported by most of the studies, and thus, were not included here.

\section{Computation and analysis of effect sizes}

All studies used scores at the SVS as independent variables, with an array of other variables serving as dependent variables. The interest in the present study is the interaction between the participants' SVS results and region of residence and birth, mostly reported in $\mathrm{F}$ values and means for the scores on the 10 motivational types described by Schwartz (Schwartz, 1992). Thus, in this review we used the scores on SVS as dependent variables, with region of the country as independent variable. In order for studies with larger sample sizes to carry more weight in the analyses than smaller studies, each sample size was weighted by its sample using the inverse variance weight (w). This created an averaged squared deviation around the mean, but weighted by sample size so that estimates from large samples had a larger weight (Hedges \& Olkin, 1985). Effect sizes were then compared by a series of between-subjects ANOVA designs, later examined with Bonferroni and Tukey HSB post-hoc tests.

\section{RESULTS}

A Univariate ANOVA weighted by sample size was carried on for each of the 10 motivational types. Differences between Brazilian regions were statistically different for Self-direction $(F(4,49)=2.87, p=0.034$, $\left.\mathrm{w}^{2}=0.73\right)$, Stimulation $\left(\mathrm{F}(4,49)=2.76, \mathrm{p}=0.039, \mathrm{w}^{2}=0.71\right)$, Achievement $\left(\mathrm{F}(4,49)=5.32, \mathrm{p}=0.001, \mathrm{w}^{2}=\right.$ 0.96), Power $\left(F(4,49)=3.66, p=0.011, w^{2}=0.84\right)$, Security $\left(F(4,48)=3.97, p=0.008, w^{2}=0.87\right)$, Conformity $\left(\mathrm{F}(4,48)=6.04, \mathrm{p}=0.001, \mathrm{w}^{2}=0.98\right)$, Tradition $\left(\mathrm{F}(4,48)=5.25, \mathrm{p}=0.002, \mathrm{w}^{2}=0.95\right)$, Benevolence $(\mathrm{F}(4,49)$ 
$\left.=3.55, \mathrm{p}=0.013, \mathrm{w}^{2}=0.83\right)$ and Universalism $\left(\mathrm{F}(4,49)=4.28, \mathrm{p}=0.005, \mathrm{w}^{2}=0.90\right)$. Descriptive statistics and post-hoc results are presented on Table 2 .

TABLE 2. Descriptive statistics and post-hoc results for Motivational Types.

\begin{tabular}{|c|c|c|c|c|c|c|c|c|c|c|c|c|c|c|c|c|c|c|}
\hline \multirow[b]{3}{*}{ Region } & \multicolumn{18}{|c|}{ Motivational types } \\
\hline & \multicolumn{2}{|c|}{$\begin{array}{c}\text { Self- } \\
\text { direction }\end{array}$} & \multicolumn{2}{|c|}{ Stimulation } & \multicolumn{2}{|c|}{ Achievement } & \multicolumn{2}{|c|}{ Power } & \multicolumn{2}{|c|}{ Security } & \multicolumn{2}{|c|}{ Conformity } & \multicolumn{2}{|c|}{ Tradition } & \multicolumn{2}{|c|}{ Benevolence } & \multicolumn{2}{|c|}{ Universalism } \\
\hline & $\begin{array}{l}\text { Mean } \\
\text { (Sd) }\end{array}$ & $\mathbf{N}$ & $\begin{array}{l}\text { Mean } \\
\text { (Sd) }\end{array}$ & $\mathbf{N}$ & $\begin{array}{l}\text { Mean } \\
\text { (Sd) }\end{array}$ & $\mathbf{N}$ & $\begin{array}{l}\text { Mean } \\
\text { (Sd) }\end{array}$ & $\mathbf{N}$ & $\begin{array}{l}\text { Mean } \\
\text { (Sd) }\end{array}$ & $\mathbf{N}$ & $\begin{array}{l}\text { Mean } \\
\text { (Sd) }\end{array}$ & $\mathbf{N}$ & $\begin{array}{l}\text { Mean } \\
\text { (Sd) }\end{array}$ & $\mathbf{N}$ & $\begin{array}{l}\text { Mean } \\
\text { (Sd) }\end{array}$ & $\mathbf{N}$ & $\begin{array}{l}\text { Mean } \\
\text { (Sd) }\end{array}$ & $\mathbf{N}$ \\
\hline & 5.34 & & 3.88 & & 4.85 & & 3.21 & & 5.08 & & 5.03 & & 4.30 & & 5.38 & & 5.17 & \\
\hline & (3.53) & & $(9.02)$ & & $(4.87)$ & & $(16.95)$ & & $(4.08)$ & & $(7.07)$ & & $(6.31)$ & & $(2.80)$ & & (3.73) & \\
\hline & $4.95^{\star *}$ & & 3.81 & & 5.00 & & 3.60 & & 5.01 & & $5.39^{* * *}$ & & 4.48 & & 5.40 & & 5.19 & \\
\hline Northeast & & 14 & & 14 & & 14 & & 14 & & 13 & & 13 & & 13 & & 14 & & 14 \\
\hline & (6.14) & & $(11.41)$ & & $(4.50)$ & & $(7.60)$ & & $(4.15)$ & & $(3.86)$ & & $(4.78)$ & & (3.33) & & (3.67) & \\
\hline Center- & 5.11 & & $3.43^{* *}$ & & $4.47^{*+*}$ & & $3.16^{\star \star *}$ & & $4.83^{* * *}$ & & $4.67^{* * *}$ & & $3.66^{\star \star *}$ & & $5.17^{* *}$ & & $4.89^{*+*}$ & \\
\hline & & 12 & & 12 & & 12 & & 12 & & 12 & & 12 & & 12 & & 12 & & 12 \\
\hline & 5.41 & & 4.18 & & 5.02 & & 3.94 & & 5.25 & & $5.40^{* * *}$ & & $4.51^{\star \star *}$ & & $5.60^{* *}$ & & 5.33 & \\
\hline Southeast & & 12 & & 12 & & 12 & & 12 & & 12 & & 12 & & 12 & & 12 & & 12 \\
\hline & (6.13) & & $(14.10)$ & & (8.05) & & (10.62) & & $(4.78)$ & & (6.52) & & (8.57) & & (3.66) & & (5.64) & \\
\hline & $5.86^{* *}$ & & $4.75^{* *}$ & & $5.58^{* * *}$ & & $4.41^{* *}$ & & $5.50^{* * *}$ & & $5.66^{* * *}$ & & $4.66^{* *}$ & & $5.81^{* *}$ & & $5.68^{* * *+}$ & \\
\hline South & & 5 & & 5 & & 5 & & 5 & & 5 & & 5 & & 5 & & 5 & & 5 \\
\hline & (5.58) & & (17.78) & & (6.62) & & $(9.76)$ & & (3.66) & & (6.22) & & (8.04) & & (2.67) & & (5.07) & \\
\hline
\end{tabular}

("*) $\mathrm{p} \leq 0.01$ for Tukey and Bonferroni Tests

(*) $p \leq 0.05$ for Tukey and Bonferroni Tests

The results suggest that even though all regions presented high scores for Benevolence and Universalism values there were differences among the values each region endorses more. The North region presented higher scores for Self-direction $(5.34$, with standard deviation $=3.53)$ and Security $(5.08$ and SD $=4.08)$. In the Northeast region, the highest scores were Security (5.01; $\mathrm{SD}=4.15)$ and Conformity (5.39; $\mathrm{SD}=3.86)$. The Center-West region presented higher scores for Self-direction (5.11; SD = 5.27) and Security (4.83 with SD = 6.23). Self-direction (5.41; $\mathrm{SD}=6.13)$ and Conformity (5.40 and $\mathrm{SD}=6.52)$ were the highest scores in the Southeast region and the Southern region presented higher scores for Self-direction (5.86 with SD = 5.58) and Conformity (5.66 with $\mathrm{SD}=6.22$ ).

\section{DISCUSSION}

We found supporting evidence for Hypothesis 1 that specified that respondents from Brazil would endorse values differently. There are historic and socialization differences in these regions which have been described previously are associated with the values endorsed by the residents of these regions.

However it is interesting to note that all regions presented at least one Conservation value and among them the Northeast and Southern regions have stood out. The Northeast stands out because its two highest scores were Conservation values (Security and Conformity), and the Southern region for presenting the highest Conformity score among the five regions (5.66; $\mathrm{SD}=6.22$ ). This fact corroborates the claims of Ribeiro (1997), Lesser (2001) and Woortman (2007) on the African and European immigration in Brazil.

The Hypotheses 2 predicted that respondents from the Southern, North, and Northeast regions of Brazil will show a higher endorsement for the values of Conservation such as Conformity, Tradition, and Security, when compared to respondents form the Center-West region. This hypothesis was partially confirmed. When compared to the Center-West region Conformity values were higher in the Northeast, Southeast and Southern regions, Tradition values were higher on the Southern and Southeast regions, and Security values were higher on the Southern region. However these effects were not observed in the North region.

The strong emphasis on group norms, loyalty and commitment to group goals are characteristics of social systems associated with Native Brazilians which seem to be reflected in the preference for Conservation values 
of people in the Northeast, Southeast and Southern regions. Values of Conformity, Tradition and Security refer to the needs of belonging to the group (Schwartz et al., 2012). However, the North region should have presented the same results. Perhaps this can be explained by the difficulty of data collection in locations with lack of development away from urban centers given the difficulty of transportation and communication. It is likely that participants in studies involving the North region do not reflect the majority of its residents, but the inhabitants of large urban centers. The Center-West endorsement of group interests found in other regions does not seem to be sustained given the high political and economic development that can manifest itself in a lower emphasis on values oriented to group interests.

There has been higher endorsement of Stimulation and Universalism values in the Southern region when compared to the Center-West. This result confirms Hypothesis 3 that respondents from the Southern region of Brazil show a higher endorsement of the values of Stimulation and Universalism when compared to respondents from the Center-West region of Brazil. That is, although the rapid economic and political development of the Center-West region call for a greater endorsement of values more oriented to personal interests than to group interests when compared to the residents of the Southern region this preference dos not stand out. The residents of the Southern region emphasize the personal interest that the Stimulation values represents and the Universalism values that are both personal and collective, as expected of European immigrants in the nineteenth century (Lesser, 2001). Besides, the residents of the Southern region also value more Self-direction than the Northeast residents, reinforcing the emphasis on personal interests. However, it should be noted that the results also showed that the Southern region had the highest average in all basic values. This result can be derived from a problem of response styles when rating values within the Schwartz Values Survey (SVS).

When evaluating the results for the three hypotheses one can see that the Conservation, Stimulation and Universalism values in the Southern and Northeast are much higher when compared to the Center-West region. One possible explanation for this difference may be linked to the fact that many samples of CenterWest studies were collected in Brasilia, a city created in the 1960s and which has attracted a great migratory movement formed by individuals from all regions of the country. That could explain the lower scores for the Conservation, Stimulation and Universalism values in this region, when compared to the other regions. Yet, these results should be considered with caution. Within the $24 \%$ of the studies included samples from this region, about $69 \%$ of them came from data collected in Brasilia. As noted before, the CW region had a remarkable economical and political development after the transfer of Brazil's administrative capital to this city. Consulting the available research and literature, we can observe the occurrence of an equivalent of a melting pot effect (Ferdman, 1995) for this region, with an observable mixture of migrants from all over the country, who established their residence in the capital of the country. It is possible to assume, thus, that respondents of this sample would endorse more values such as power or achievement - personal focused values. At the same time, this region still has large rural areas with small populations devoted to subsistence agriculture. In those places, we would expect group goals to be put ahead of individual goals, and thus, a disposition for group-oriented values should be encountered. Yet, due to this limitation regarding the sample distribution of the present study, such interpretations deserve to be more carefully investigated. Further studies could also employ more systematic historical and economic analyses to determine the origins of these value differences (van Herk \& Poortinga, 2012).

\section{CONCLUSION}

Cross-cultural researchers have been conducting several studies of basic personal values to compare individuals from different social systems. Generally, these studies seek to investigate differences in specific behaviors in several samples from different countries or ethnic groups. However, as noted by Porras and Robertson (1992) there is often bigger variance within a country than between countries. In Latin America, Hofstede et al. (2010) demonstrated differences between Brazilian regions in the cultural-level of analysis. The objective of the present study was to conduct a meta-analysis to test the differences in basic personal values within Brazil, as measured by Schwartz' Values Scale (Schwartz, 1992). Results suggested differences on the human values hierarchy adopted by the participants from the five regions of Brazil.

Although results corroborate findings from studies by other authors, it is important to highlight some limitations of the meta-analysis. One of these limitations was the criteria to only use studies that measured 
values by using the Schwartz Values Inventory (1992). Thus, several studies that used other instruments, such as the Portraits Questionnaire that could contribute to a more comprehensive view of the differences of basic personal values of the different regions of Brazil were excluded. Another limitation of the study was the high scores found for all the basic values of the Southern region, due probably to the inability to control the effect of the use of the scale in different regions.

In summary, we have identified systematic differences in the basic personal values between the five regions of Brazil and more have opened up the path for future research examining plausible historical and economic predictors of value change within large countries such as Brazil.

\section{REFERENCES}

References marked with an asterisk indicate studies included in the meta-analysis.

Alexander, A. C., Inglehart, R., \& Welzel, C. (2011). Measuring effective democracy: a defense. World Values Research, 4(1), 1-39.

Allen, M. W. (2000). The attribute-mediation and product meaning approaches to the influences of human values on consumer choices. In F. Columbus (Ed.). Advances in psychology research (Vol. 1, pp. 31-76). Huntington, NY: Nova Science.

Alfinito, S., \& Torres, C. V. (2012). Modelo de influência cultural no consumo: uma proposta baseada em axiomas sociais. Revista de Administração Mackenzie, 13, 15-38.

*Borges, L. O. (2000). A trajetória ocupacional, valores humanos e a síndrome de burnout: um estudo de caso com os exfuncionários do BANDERN. (Relatório de pesquisa). Natal: BANDERN.

Campos, C. B., \& Porto, J. B. (2010). Escala de Valores Pessoais: validação da versão reduzida em amostra de trabalhadores brasileiros. Psico, 41(2), 208-213.

Ettorre, B. (1998). A business case for today's Brazil and Argentina. Management Review, 87(9), 10-15.

Feather, N. T. (1982). Human values and the prediction of action: an expectancy-value analysis. In N. T. Feather (Org.). Expectation and actions: expectancy-value models in psychology. Hillsdale, NY: Laurence Earlbaum.

* Félix, M. L. (2010). Valores pessoais e percepção de valores organizacionais: influências na adoção de comportamento de saúde (Unpublished Master 's thesis). Universidade Católica de Brasília, Brasília.

Ferdman, B. M. (1995). Cultural identity and diversity in organizations: Bridging the gap between group differences and individual uniqueness. In M. Chemers, S. Oskamp, \& M. A. Costanzo (Eds.). Diversity in organizations: New perspectives ofr a changing workplace (pp. 37-61). Thousand Oaks, CA: Sage.

* Fernandes, H. A., Ferreira, M. C. (2009). O impacto dos valores pessoais e organizacionais no comprometimento com a organização. Psico-USF, 14(3), 341-354.

Fischer, R., \& Poortinga, Y. (2012). Are cultural values the same as the values of individuals? An examination of similarities in personal, social and cultural value structures. International Journal of Cross-Cultural Management, 12, 157-170. doi:10.1177/1470595812439867

Fischer, R. \& Schwartz, S. H. (2011). Whence Differences in Value Priorities? Individual, Cultural, or Artifactual Sources. Journal of Cross-Cultural Psychology, 42, 1127-1144. doi:10.1177/0022022110381429

${ }^{*}$ Fischer, R., Smith, P., Richey, B., Ferreira, M. C., Assmar, E. M. L., Maes, J., \&Stumpf, S. (2007). How do organizations allocate rewards? The predictive validity of national values, economic and organizational factors across six nations. Journal of CrossCultural Psychology, 38(1), 3-18. doi: 10.1177/0022022106295437

* Fiuza, G. D. (2010). Políticas de gestão de pessoas, valores pessoais e justiça organizacional. Revista de Administração Mackenzie, 11(5), 55-81.

Geiger, P. P. (1967). Geografia e planejamento. Revista Brasileira de Geografia, 29(3), 25-58.

Georgas, J. Berry, J. W., Vijver, F. J. R.van de, Kagitçibasi, C. \& Poortinga Y. H. (2006). Families across cultures: A 30-nation psychological study. Cambridge, U.K.: Cambridge University Press

Gomes, M. A. (2008). Antes do Kasato Maru: centenário da colônia agrícola japonesa na fazenda Santo Antônio. Macabú: Rio de Janeiro.

Gouveia, V. V. (2003). A natureza motivacional dos valores humanos: evidencias acerca de uma nova tipologia. Estudos de Psicologia (Natal), 8(3), 431-443. doi:10.1590/S1413-294X2003000300010 
* Gouveia, V. V., Martínez, E., Meira, M., \& Milfont, T.L. (2001). A estrutura e o conteúdo universais dos valores humanos: Análise fatorial confirmatória da tipologia de Schwartz. Estudos de Psicologia, 6(2), 133-142. doi:10.1590/S010237722007000100008

Hedges, L. V., \& Olkin, I. (1985). Statistical methods for meta-analysis. New York: Academic Press.

van Herk, H., \& Poortinga, Y. (2012). Current and historical antecedents of individual value differences across 195 regions in Europe. Journal of Cross-Cultural Psychology, 43, 1229-1248. doi:10.1177/0022022111429719

van Horn, K. R., Garian, K. R., Souza, E. Z., \& Feijó, M. (1995). Cultural attitudes and values in Brazilian and U.S. college students. XXV Interamerican Congress of Psychology. San Juan, Porto Rico.

van Horn, K. R., \& Marques, J. C. (1999). Development of interpersonal negotiation strategies in Brazilian adolescents. Interamerican Journal of Psychology, 32, 21-31.

Hofstede, G. (1991). Cultures and organizations: Software of the mind. Maidenhead, UK: McGraw-Hill.

Hofstede, G. (1993). Cultural constrain in management theories. Academy of Management Executive, 7, 81-94. doi:5465/ AME.1993.9409142061

Hofstede, G., Garibaldi de Hilal, A. V, Malvezzi, S., Tanure, B., \& Vinken, H. (2010). Comparing regional cultures within a country: lessons from Brazil. Journal of Cross-Cultural Psychology, 41(3), 336-352. doi:10.1177/0022022109359696

Instituto Brasileiro de Geografia e Estatística. (2012). Razões da Imigração Japonesa. Recuperado em 27 dezembro, 2012, de http://brasil500anos.ibge.gov.br/en/territorio-brasileiro-e-povoamento/japoneses/razoes-da-emigracao-japonesa.

* Lauer, I. D. L. (2003). Expectativas quanto ao primeiro emprego: Estrutura conceitual e relação com valores (Unpublished Master thesis), Universidade Federal do Pará, Belém.

Lesser, J. (2001). Negociando a identidade nacional: Imigrantes, minorias e a luta pela etnicidade no Brasil. UNESP: São Paulo.

Li, L. M. W., \& Bond, M. H. (2010). Analyzing national change in citizen secularism across four time periods in the World Values Surveys. World Values Research, 3(2), 0-13.

Mattila, A. S. (1999). The Role of Culture in the Service Evaluation Process. Journal of Service Research, 1(3), 250-61.

* Monteiro, R. S. (2005). Predisposição a confiar em emrpesas em recuperação financeira: a influência das crenças relativas a organizações e valores dos gestores credores (Unpublished Master thesis). Universidade Presbiteriana Mackenzie, São Paulo, SP, Brazil.

* Moreira, A. (2000). Valores e Dinheiros: Um estudo trancultural da relação entre prioridades de valores e significado do dinheiro para indivíduos. (Unpublished doctoral dissertation). Universidade de Brasília, Brasília.

Nakata, C., \& Sivakuma, K. (2001). Instituting the marketing concept in a multinational setting: the role of national culture. Journal of the Academy of Marketing Science, 29(3), 255-275. doi:10.1177/03079459994623

${ }^{*}$ Nepomuceno, M. V., \& Porto, J. B. (2010). Human values and attitudes toward bank services in Brazil. International Journal of Bank Marketing, 28, 168-192.

Oliven, G. R. (1992). A parte e o todo: A diversidade cultural no Brasil-nação Petrópolis, RJ: Vozes.

* Pantoja, M. J., Porto, J. B., Mourão, L. \& Borges-Andrade, J. E. (2005). Valores, Suporte Psicossocial e Impacto do Treinamento no Trabalho. Estudo de Psicologia, 10(2), 255-265. doi:10.1590/S1413-294X2005000200013

Pearson, V. M., \& Stephan, W. G. (1998). Preferences for styles of negotiation: A comparison of Brazil and the U.S. International. International Journal of Intercultural Relations, 22, 67-83. doi:10.1590/S0102-37722007000100008

Penha, E. A. (1993). A criação do IBGE no contexto da centralização política do Estado Novo. Rio de Janeiro: CCDI/IBGE

Poortinga, Y. H., \& Sinha, J. B. (1992). Methodological concerns, choice of groups and instruments. In R. DeRidder, \& R. C. Tripathi (Eds.), Norm violation and intergroup relations (pp. 38-50). New York: Oxford University Press.

Porras, J. I., \& Robertson, P. J. (1992). Organizational development: Theory, practice and research. In M. D. Dunnette, \& L. M. Hough (Eds.). Handbook of industrial and organizational psychology (2nd ed., v. 3, pp. 719-822). Palo Alto, CA: Consulting Psychologists Press.

* Porto, J. B. (2004). Estrutura e Transmissão dos Valores Laborais: Um Estudo com Estudantes Universitários (Unpublished Doctoral dissertation). Universidade de Brasília, Brasília.

${ }^{*}$ Porto, J. B. \& Tamayo, A. (2002). Prioridades axiológicas e regiões brasileiras: preditores de civismo nas organizações. Revista Psicologia: Organizações e Trabalho, 2(1), 31-61. 
Porto, J. B., \& Tamayo, A. (2007). Estrutura dos valores pessoais: a relação entre valores gerais e laborais. Revista Psicologia: Teoria e Pesquisa, 23(1), 63-70. doi: 10.1590/S0102-37722007000100008

* Porto, R.B. (2005). Valores humanos pessoais e significados do produto como preditores de preferência por tipos de automóveis (Unpublished Master thesis). Universidade de Brasília, Brasília.

Ribeiro, D. (1997). O povo brasileiro: a formação e sentido do Brasil [Brazilian people: The formation and meaning of Brazil]. São Paulo: Companhia das Letras.

Rokeach, M. (1968). Beliefs, attitudes, and values: a theory of organization and change. San Francisco, CA: Jossey-Bass.

Rokeach, M. (1973). The nature of human values. New York: The Free Press.

Ruyter, K. de, Birgelen, M. van, \& Wetzels, M. (1998). Consumer Ethnocentrism in International Service Marketing. International Business Review, 7, 185-202. doi:10.1016/S0969-5931(98)00005-5

Saris, W. E., \& Gallhofer, I. N. (2007). Design, evaluation, and analysis of questionnaires for survey research. Hoboken, NJ: Wiley.

Schwartz, S. H. (1992). Universals in the content and structure of values: Theoretical advances and empirical tests in 20 countries. In M. P. Zanna (Ed.). Advances in Experimental Social Psychology, (V. 24, pp. 1-65). San Diego: Academic.

Schwartz, S. H. (2005). Valores humanos básicos: seu contexto e estrutura inter-cultural. In A. Tamayo, \& J. B. Porto (Eds.). Valores e Comportamento nas Organizações. Rio de Janeiro: Vozes.

Schwartz, S. H. (2011). Studying Values: Personal Adventure, Future Directions. Journal of Cross-Cultural Psychology, 42(2), 307319. doi:10.1177/0022022110396925

Schwartz, S. H., Cieciuch, J., Vecchione, M., Davidov, E., Fischer, R., Beierlein, C.... Konty, M. (2012). Refining the theory of basic individual values. Journal of personality and social psychology, 103(4), 663-88. doi:10.1037/a0029393

Smith, P. B., \& Bond, M. H. (1999). Social Psychology across cultures. Massachusetts: Viacom Company.

Smith, P. B., Fischer, R., Vignoles, V., \& Bond, M. H. (2013). Understanding Social Psychology across Cultures. Engaging with others in a changing world (2nd ed.). London: SAGE.

Smith, P. B., Peterson, M. F., Akande, D., Callan, V., Cho, N. G., Jesuino, J., ... Viedge, C. (1994). Organizational event management in fourteen countries: A comparison with Hofstede's dimensions. In A. M. Bouvy, F. van der Vijver, P. Schmitz, \& P. Boski (Eds.). Journeys into cross-cultural psychology (pp. 364-373). Amsterdam: Swets \& Zeitlinger.

Smith, P. B., Torres, C. V., Leong, C.H., Budhwar, P., Achoui, M., \& Lebedeva, N., (2012). Are indigenous approaches to achieving influence in business organizations distinctive? A comparative study of guanxi, wasta, jeitinho, svyazi, and 'pulling strings'. International Journal of Human Resource Management, 23, (333-348).

* Tamayo, A. (2001). Prioridades axiológicas, atividade física e estresse ocupacional. Revista de Administração Contemporânea, 5(3), 127-147. doi: 10.1590/S1415-65552001000300007

* Tamayo, A. (1994). Hierarquia de valores transculturais e brasileiros. Revista Psicologia: Teoria e Pesquisa, 10, 269-285.

* Tamayo, A. (2002). Valores e exaustão emocional. Revista de Administração da Universidade de São Paulo, 37(2), 26-37.

Tamayo, A., \& Schwartz, S. H. (1993). Estrutura motivacional dos valores. Revista Psicologia: Teoria e Pesquisa, 9, $329-348$.

* Tamayo, A., Souza, M.G.S., Vilar, L.S., Ramos, J.L., Albernaz, J.V., Ferreira, N.P. (2001). Prioridades Axiológicas e Comprometimento Organizacional. Revista Psicologia: Teoria e Pesquisa, 17(1), 27-35.

Torres, C. V. (2009). Do social norms have an influence in leadership style preference? Assessing leadership style differences between Americans and Brazilians. London: Verlag Dr. Muller.

Torres, C. V., \& Dessen, M. A. (2006). The Brazilian jeitinho: Brazil's sub-cultures, its diversity of social contexts, and its family structures. In J. Georgas, J. W. Berry, F. J. R. van de Vijver, C. Kagitçibasi, \& Y. H. Poortinga (Eds.). Families across cultures: A 30-nation psychological study (pp. 259-267). Cambridge, U.K.: Cambridge University Press.

Torres, C. V., \& Dessen, M. A. (2008). Brazilian culture, family, and its ethnic-cultural variety. Arizona Journal of Hispanic Cultural Studies, 12, 41-62.

Triandis, H. C. (1994). Cross-cultural industrial and organizational psychology. In H. C. Triandis, M. D. Dunnette, \& L. M. Hough (Eds.). Handbook of industrial and organizational psychology (2nd ed., vol. 4, pp. 103-172). Palo Alto, CA: Consulting Psychologists Press.

Triandis, H. C., \& Gelfand, M. J. (1998). Converging measurement of horizontal and vertical individualism and collectivism. Journal of Personality and Social Psychology, 74, 118-129. doi: 10.1037/0022-3514.74.1.118 
Triandis, H. C., McCusker, C., \& Hui, C. H. (1990). Multimethod probes of individualism and collectivism. Journal of Personality \& Social Psychology, 59, 1006-1020. doi:10.1037/0022-3514.59.5.1006

Welzel, C. (2014). Freedom rising: Human empowerment and the quest for emancipation. New York, NY: Cambridge University Press.

Woortman, E. F. (2007). Cambios de tiempo y espacio, cambios sociales, bajo el impacto de la modernización [Changes in time and space, social changes, under the impacto of modernization]. Estudos Feministas, 15(2), 476-484. doi:10.1590/S0104026X2007000200015 